\title{
Biosynthesized Poly(3-Hydroxybutyrate) on Coated Pineapple Leaf Fiber Papers for Biodegradable Packaging Application
}

\author{
Pilanee Vaithanomsat ${ }^{1,2} \mathbb{D}$, Kunat Kongsin ${ }^{1,3}$, Chanaporn Trakunjae ${ }^{1,4} \mathbb{D}$, Jirachaya Boonyarit ${ }^{1}$, Amnat Jarerat ${ }^{5}$, \\ Kumar Sudesh 4 (D) and Rungsima Chollakup ${ }^{1, *(\mathbb{D})}$
}

1 Kasetsart Agricultural and Agro-Industrial Product Improvement Institute (KAPI), Kasetsart University, Bangkok 10900, Thailand; aappln@ku.ac.th (P.V.); kunat.k@ku.th (K.K.); aapcpt@ku.ac.th (C.T.); aapjab@ku.ac.th (J.B.)

2 Center for Advanced Studies in Tropical Natural Resources, National Research University-Kasetsart University, Kasetsart University, Bangkok 10900, Thailand

3 Biotechnology of Biopolymers and Bioactive Compounds Special Research Unit, Department of Biotechnology, Faculty of Agro-Industry, Kasetsart University, Bangkok 10900, Thailand

4 Ecobiomaterial Research Laboratory, School of Biological Sciences, Universiti Sains Malaysia, Penang 11800, Malaysia; ksudesh@usm.my

5 Food Technology Program, Kanchanaburi Campus, Mahidol University, Kanchanaburi 71150, Thailand; amnat.jar@mahidol.edu

* Correspondence: aaprmc@ku.ac.th; Tel.: +66-2-942-8600

Citation: Vaithanomsat, P.;

Kongsin, K.; Trakunjae, C.;

Boonyarit, J.; Jarerat, A.; Sudesh, K.; Chollakup, R. Biosynthesized Poly(3-Hydroxybutyrate) on Coated Pineapple Leaf Fiber Papers for Biodegradable Packaging Application. Polymers 2021, 13, 1733.

https://doi.org/10.3390/ polym13111733

Academic Editors: Farayde

Matta Fakhouri

and José Ignacio Velasco

Received: 23 April 2021

Accepted: 16 May 2021

Published: 26 May 2021

Publisher's Note: MDPI stays neutral with regard to jurisdictional claims in published maps and institutional affiliations.

Copyright: (c) 2021 by the authors. Licensee MDPI, Basel, Switzerland. This article is an open access article distributed under the terms and conditions of the Creative Commons Attribution (CC BY) license (https:// creativecommons.org/licenses/by/ $4.0 /)$.
Abstract: This paper is aimed at investigating the usage of biosynthesized poly(3-hydroxybutyrate) $(\mathrm{P}(3-\mathrm{HB}))$ for a coating on pineapple leaf fiber paper (PLFP). For this purpose, $(\mathrm{P}(3-\mathrm{HB}))$ was produced by Rhodococcus pyridinivorans BSRT1-1, a highly potential $\mathrm{P}(3-\mathrm{HB})$ producing bacterium, with a weight-average molecular weight $\left(M_{\mathrm{W}}\right)$ of $6.07 \times 10^{-5} \mathrm{~g} / \mathrm{mol}$. This biosynthesized $\mathrm{P}(3-\mathrm{HB})$ at $7.5 \%(w / v)$ was then coated on PLFP through the dip-coating technique with chloroform used as a solvent. The respective coated PLFP showed that $\mathrm{P}(3-\mathrm{HB})$ could be well coated all over on the PLFP surface as confirmed by scanning electron microscopy (SEM) and Fourier transform infrared (FTIR) spectroscopy. The brightness and mechanical properties of PLFP could be improved by coating with biosynthesized $\mathrm{P}(3-\mathrm{HB})$ in comparison to commercially available $\mathrm{P}(3-\mathrm{HB})$ and non-coated PLFP. Furthermore, coating of $\mathrm{P}(3-\mathrm{HB})$ significantly increased the water drop penetration time on the surface of PLFP and was similar to that of the commercial P(3-HB) with the same content. The results showed that all the coated PLPF samples can be degraded under the soil burial test conditions. We have demonstrated that the $\mathrm{P}(3-\mathrm{HB})$ coated PLFP paper has the ability to prevent water drop penetration and could undergo biodegradation. Taken together, the $\mathrm{P}(3-\mathrm{HB})$ coated PLFP can be applied as a promising biodegradable paper packaging.

Keywords: poly(3-hydroxybutyrate); pineapple leaf fiber; paper; dip-coating; biodegradable packaging; soil burial test

\section{Introduction}

Pineapple leaves are important agricultural waste generated from pineapple cultivation, especially in tropical countries such as the Philippines, Brazil, Costa Rica, Thailand and China [1]. It has been documented that pineapple leaf fiber possesses high percentage of cellulose content (70-82\%), excellent tensile strength and high toughness, which make them suitable for applying in term of reinforcing composites [2-6]. Besides, pineapple leaf fiber paper could be considered as an outstanding resource for pulp and paper production due to its favorable mechanical properties and high cellulose content $[1,7]$.

In recent years, the increase of consumer awareness on reducing synthetic packaging waste have put new demands on the development of edible/biodegradable packaging from natural materials [8]. Biodegradable paper is also widely developed for food packaging purposes. However, the paper requires a coating process to improve barrier and water 
protection properties [9]. Petroleum-based derivatives such as polyethylene (PE), ethylene vinyl alcohol (EVOH), polyvinylidene chloride (PVDC), waxes and/or fluorine-derivatives are typically used as coating materials for papers. These synthetic polymers aggravate environmental and economic concerns because of their poor recyclability of coated papers and lack of biodegradation. From a sustainable point of view, several bio-based polymers have become interesting in terms of paper or paperboard coatings such as polysaccharides, proteins, lipids, biodegradable polyesters (poly-hydroxyalkanoate (PHA) and polylactic acid (PLA)) $[9,10]$.

Poly(3-hydroxybutyrate) $(\mathrm{P}(3-\mathrm{HB}))$ is the most common PHA, which is produced and accumulated intracellularly by various kinds of microorganisms as carbon and energy sources under the nutrient limitation [11]. The $\mathrm{P}(3-\mathrm{HB})$ is currently serving as an attractive bioplastic that can be applied in various research fields including polymer blends, nanocomposites, food packaging films and biomedical materials due to being fully biodegradable and biocompatible $[12,13]$. Additionally, several authors reported that $\mathrm{P}(3-\mathrm{HB})$ can be used as a bio-based coating to improve surface hydrophobicity and mechanical properties of papers or paper board [14-16]. The coating of $\mathrm{P}(3-\mathrm{HB})$ on papers could be carried out by different techniques such as dip coating/solvent casting [16,17], extrusion coating [18] and compression molding [19-21]. However, the dip coating is considered to be a facile method of applying an aqueous coating solution over the paper, which is practically applied in the laboratory scale and the coating performance can be quickly determined [10]. We recently reported the production of biosynthesized $\mathrm{P}(3-\mathrm{HB})$ by a newly isolated rare actinomyces Rhodococcus pyridinivorans BSRT1-1 [22]. However, the application of this newly biosynthesized has not been reported so far.

Therefore, this study aimed to produce $\mathrm{P}(3-\mathrm{HB})$ from Rhodococcus pyridinivorans BSRT1-1, a rare $\mathrm{P}(3-\mathrm{HB})$ producing bacterial strain and utilize as a coating material on PLFP through the dip-coating method with chloroform used as a solvent. The effect of the biosynthesized $\mathrm{P}(3-\mathrm{HB})$ coating on physical, mechanical and water absorption properties of coated PLFPs were evaluated and compared to that of the commercial $\mathrm{P}(3-\mathrm{HB})$ coating. In addition, biodegradability of biosynthesized P(3-HB) coated PLPF was evaluated by soil burial test.

\section{Materials and Methods}

\subsection{Materials and Chemicals}

A commercial poly(3-hydroxybutyrate) ( $\mathrm{P}(3-\mathrm{HB}))$, with a weight-average molecular weight $\left(M_{\mathrm{w}}\right)$ of $5.50 \times 10^{5} \mathrm{~g} / \mathrm{mol}$, was supplied by Goodfellow, Cambridge Ltd., Huntingdon, England, UK. Pineapple leaf fibers were produced using a decorticating machine by a group of farmers in Ban Kha, Ratchaburi, Thailand. The obtained pineapple leaf fibers were washed several times with tap water and then dried and stored in a plastic bag at room temperature until used. Chloroform (analytical grade) was provided from VWR Chemicals, Radnor, PA, USA.

\subsection{Bacterial Strain and Media}

Rhodococcus pyridinivorans BSRT1-1 was isolated from the soil by Enzyme and Microbial Technology Laboratory, Kasetsart Agricultural and Agro-Industrial Product Improvement Institute (KAPI), Kasetsart University, Bangkok, Thailand, which was previously identified as a high potential $\mathrm{P}(3-\mathrm{HB})$ producing bacterium [22]. The minimal medium $(\mathrm{MM})$ was used for $\mathrm{P}(3-\mathrm{HB})$ production consisting of $\mathrm{NH}_{4} \mathrm{Cl}, 0.5 \mathrm{~g} / \mathrm{L} ; \mathrm{KH}_{2} \mathrm{PO}_{4}, 2.8 \mathrm{~g} / \mathrm{L}$; $\mathrm{Na}_{2} \mathrm{HPO}_{4}, 3.32 \mathrm{~g} / \mathrm{L} ; \mathrm{MgSO}_{4} \cdot 7 \mathrm{H}_{2} \mathrm{O}, 0.25 \mathrm{~g} / \mathrm{L}$, and $1 \mathrm{ml} / \mathrm{L}$ of trace element (TE) solution. The TE solution was comprised of: $\mathrm{ZnSO}_{4} \cdot 7 \mathrm{H}_{2} \mathrm{O}, 1.3 \mathrm{~g} / \mathrm{L} ; \mathrm{FeSO}_{4} \cdot 7 \mathrm{H}_{2} \mathrm{O}, 0.2 \mathrm{~g} / \mathrm{L}$; $\left(\mathrm{NH}_{4}\right)_{6} \mathrm{Mo}_{7} \mathrm{O}_{24} \cdot 4 \mathrm{H}_{2} \mathrm{O}, 0.6 \mathrm{~g} / \mathrm{L} ; \mathrm{H}_{3} \mathrm{BO}_{3}, 0.6 \mathrm{~g} / \mathrm{L}$, and $\mathrm{CaCl}_{2}, 0.2 \mathrm{~g} / \mathrm{L}$. Fructose and $\mathrm{KNO}_{3}$ were used as carbon and nitrogen sources for $\mathrm{P}(3-\mathrm{HB})$ production by this strain. 


\subsection{Production and Purification of Poly (3-Hydroxybutyrate)}

Production and purification of $\mathrm{P}(3-\mathrm{HB})$ were conducted in accordance with the method described previously [22]. Briefly, $R$. pyridinivorans BSRT1-1 was activated in tryptic soy agar (TSA) plate and incubated at $35{ }^{\circ} \mathrm{C}$ for $24 \mathrm{~h}$. The respective colonies were transferred into 250 flask containing $50 \mathrm{~mL}$ of in tryptic soy broth (TSB) and incubated in a rotary shaker at $35^{\circ} \mathrm{C}, 180 \mathrm{rpm}$ for $18 \mathrm{~h}$. The obtained culture was then inoculated into a $10 \mathrm{~L}$ stirred tank fermenter containing $6 \mathrm{~L}$ of minimal medium $(\mathrm{MM})$ at $35^{\circ} \mathrm{C}$ for $48 \mathrm{~h}$ with aeration rate at $0.75 \mathrm{vvm}$, agitation rate at $180 \mathrm{rpm}$ and controlling of $\mathrm{pH}$ to neutral within fermentation period. The bacterial cell was harvested after fermentation and then freeze dried at $-80^{\circ} \mathrm{C}$. The dried cell was extracted with chloroform at ratio of 1:100 $(w / v)$ under continuous stirring at ambient temperature for 3 days. The bacterial cell debris was removed by filtration with Whatman No.1. The filtered solution was concentrated using rotary evaporation and followed by slow dropwise into cold method in order to precipitated and purify $\mathrm{P}(3-\mathrm{HB})$. The purified $\mathrm{P}(3-\mathrm{HB})$ was collected by centrifuge (Kubota 6500, Osaka, Japan) at 10,000 $\times g, 4^{\circ} \mathrm{C}$ for $10 \mathrm{~min}$ and air dried for overnight.

\subsection{Characterization of Poly (3-Hydroxybutyrate)}

The weight-average molecular weight $\left(M_{\mathrm{w}}\right)$, number-average molecular weight $\left(M_{\mathrm{n}}\right)$ and polydispersity index (PDI) of biosynthesized $\mathrm{P}(3-\mathrm{HB})$ were analyzed by gel permeation chromatography (GPC) (Agilent 1200 GPC, Santa Clara, CA, USA), following the method that previously published [23]. The $\mathrm{P}(3-\mathrm{HB})$ solution was prepared at $1 \mathrm{mg} / \mathrm{mL}$ using chloroform as solvent and filtered through $0.22 \mu \mathrm{m}$ polytetrafluoroethylene (PTFE) membrane before analysis. The $50 \mu \mathrm{L}$ of filtered $\mathrm{P}(3-\mathrm{HB})$ solution was injected into GPC coupled with refractive index detector (RID) equipped with Shodex GPC K-806M and $\mathrm{K}-802$ column at $40{ }^{\circ} \mathrm{C}$ when chloroform used as mobile phased at $1 \mathrm{~mL} / \mathrm{min}$ of flow rate.

\subsection{Preparation of Pineapple Leaf Fiber Paper (PLFP)}

Pineapple leaf fiber paper (PLFP) was prepared by the slightly modified method previously report [24]. The pineapple leaf fiber was pretreated with $5 \%(w / v)$ of sodium hydroxide solution at $90^{\circ} \mathrm{C}$ for $4 \mathrm{~h}$ and then allowed to stand at room temperature for $18 \mathrm{~h}$. The alkaline treated fiber was washed several times with tap water until the $\mathrm{pH}$ of water reached neutral. The obtained fibers were disintegrated into pulp by a pulping machine (produced by Kasetsart Agricultural and Agro-Industrial Product Improvement Institute (KAPI), Kasetsart University, Bangkok, Thailand) for $25 \mathrm{~min}$. Polyethylene oxide agent was added into pulp and the paper was sheeted using the forming mold. The forming paper was allowed to dry at room temperature around $24 \mathrm{~h}$.

\subsection{Coating Procedure of $P(3-H B)$ on Pineapple Leaf Fiber Paper}

A commercial P(3-HB) (Goodfellow, Cambridge Ltd., Huntingdon, England, UK) was coated on PLFP with different amounts of $\mathrm{P}(3-\mathrm{HB})(5,7.5$ and $10 \%(w / v))$ by the dip-coating method as described previously [16]. The $\mathrm{P}(3-\mathrm{HB})$ solution was prepared at $60^{\circ} \mathrm{C}$ for $6 \mathrm{~h}$ using chloroform as a solvent under continuous stirring. The obtained solution was cool down to room temperature and poured into a glass tray and the PLFP was dip-coated into the $\mathrm{P}(3-\mathrm{HB})$ solution for $15 \mathrm{~min}$. The resultant PLFPs were dried at room temperature for at least $12 \mathrm{~h}$ to remove the residue of the solvent. Due to the limited amount of biosynthesized $\mathrm{P}(3-\mathrm{HB})$ samples available, the varying of $\mathrm{P}(3-\mathrm{HB})$ concentrations was not carried out. Thus, biosynthesized $\mathrm{P}(3-\mathrm{HB})$ was used to coat on PLFP at the optimum content under the same coating condition to commercial $\mathrm{P}(3-\mathrm{HB})$. All coated papers were conditioned at $23{ }^{\circ} \mathrm{C}$ and $50 \%$ relative humidity for at least $8 \mathrm{~h}$ prior to testing. The visual appearance of the non-coated and $\mathrm{P}(3-\mathrm{HB})$ coted PLFP are presented in Figure 1. 


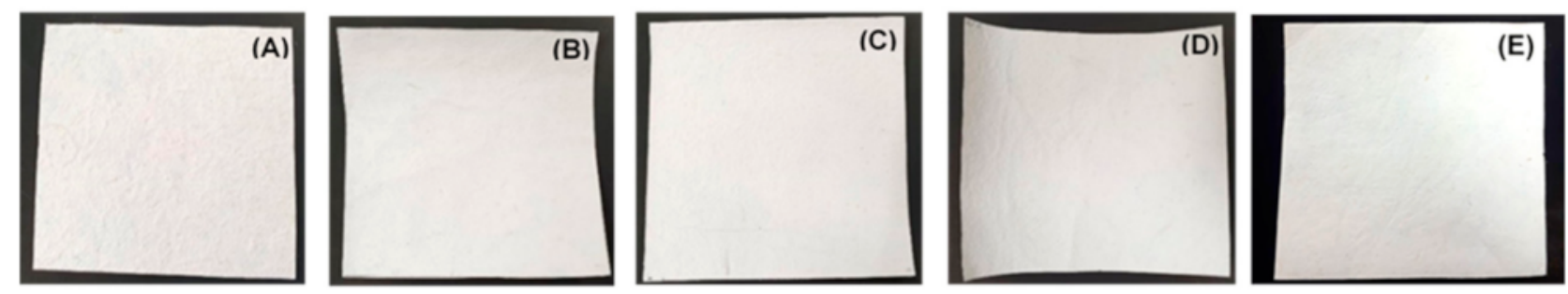

Figure 1. Visual appearance of (A) the non-coated PLFP, (B-D) the commercial P(3-HB) coated PLFPs at 5, 7.5 and $10 \%(w / v)$ and $(\mathbf{E})$ the biosynthesized $\mathrm{P}(3-\mathrm{HB})$ coated PLFP at $7.5 \%(w / v)$.

\subsection{Physical Characterization of $P(3-H B)$ Non-Coated and Coated Pineapple Fiber Paper}

2.7.1. Thickness Basis Weight and Percentage of Increasing in Weight

The thickness of paper samples was measured using a digital thickness gage (Mitutoyo, ID-C112XBS, Kanagawa, Japan) with a precision of $0.001 \mathrm{~mm}$ at least five random locations of each paper sample. The basis weight $\left(\mathrm{g} / \mathrm{m}^{2}\right)$ is referred to the weight of paper per one unit of paper area under specific relative humidity $\left(50 \%\right.$ at $\left.23{ }^{\circ} \mathrm{C}\right)$, which calculated by dividing of the weight of paper sample $(\mathrm{g})$ by the area of paper sample $\left(\mathrm{m}^{2}\right)$. The percentage increase in weight was determined following Equation (1):

The percentage increase in weight $=\left[\left(\mathrm{W}_{\mathrm{t}}-\mathrm{W}_{0}\right) / \mathrm{W}_{0} \times 100\right]$

where $\mathrm{W}_{0}$ is the initial paper weight and $\mathrm{W}_{t}$ is the coated paper weight.

\subsubsection{Color Properties}

The colorimetric parameters of paper samples were measured using a portable colorimeter (Hunter Lab Miniscan EZ 4500L, Reston, VA, USA) based on the CIELAB color system. The colorimeter was standardized with standard white and black calibration tiles prior to measuring samples. Measurements were carried out in five replicates at random positions on the PLFP surface. The color values were measured in term of $L^{*}$ (lightness), $a^{*}$ (red-green), $b^{*}$ (yellow-blue) and percentage of brightness followed by the standard method of TAPPI T 452 om-18 [25]. The total color difference $\left(\Delta E^{*}\right)$ compared with non-coated PLFP was calculated using equation (2):

$$
\Delta E^{*}=\left[\left(L^{*}\right)^{2}+\left(a^{*}\right)^{2}+\left(b^{*}\right)^{2}\right]^{1 / 2}
$$

\subsection{Scanning Electron Microscopy (SEM) of P(3-HB) Non-Coated and Coated Pineapple Fiber Paper}

The paper samples were immersed in liquid nitrogen and subsequently cut down by a sharp blade. The surface microstructure of paper samples was observed under scanning electron microscope (SEM) (Hitachi SU8020, Krefeld, Germany) with accelerating voltage of $15 \mathrm{kV}$.

\subsection{Fourier Transform Infrared Spectroscopy (FTIR) of P(3-HB) Non-Coated and Coated Pineapple Fiber Paper}

Fourier transform infrared (FTIR) spectrometer (Thermo Scientific Nicolet IR200, Waltham, MA, USA) was used to investigate the chemical functional groups on the surface of paper samples. FTIR spectra were collected over the range of $400-4000 \mathrm{~cm}^{-1}, 128$ scans and a resolution of $4 \mathrm{~cm}^{-1}$ in attenuated total reflection (ATR) mode.

\subsection{Mechanical Characterization of P(3-HB) Non-Coated and Coated Pineapple Fiber Paper \\ 2.10.1. Tensile Properties (Tensile Index and Elongation at Break)}

The tensile index of paper samples was analyzed in accordance with TAPPI T 494 om-13 [26] Schopper tensile tester (Kumagai Riki Kogyo Co., Ltd., Tokyo, Japan). Paper samples were cut into rectangular strips $(15 \mathrm{~mm} \times 150 \mathrm{~mm})$ and then clamped the both ends 
of each specimen strips with the paper-based holder. The tensile testing was performed at a strain rate of $25 \pm 5 \mathrm{~mm} / \mathrm{min}$ and a clamp distance of $100 \mathrm{~mm}$. The breaking force value $(\mathrm{N})$ was recorded and used to determine the tensile index $(\mathrm{N} \cdot \mathrm{m} / \mathrm{g})$ according to the following Equation (3):

$$
\text { Tensile index }(\mathrm{N} \cdot \mathrm{m} / \mathrm{g})=[653.8 \times \text { breaking force }] / \text { basis weight }
$$

Elongation at break (\%) was calculated by dividing the extension at the breakage by the initial gauge length of the samples and multiply by 100 .

\subsubsection{Folding Endurance}

The folding endurance test was investigate followed by TAPPI T $423 \mathrm{~cm}-07$ [27] using MIT folding endurance tester (Kumagai Riki Kogyo Co., Ltd., Tokyo, Japan). Paper sample were prepared as described in tensile testing. The applied tension was fixed at $1 \mathrm{~kg}(9.81 \mathrm{~N})$. The folding endurance or the number of double folds is defined as the number of repeated forward and backward folds the specimen, which can withstand under a $1 \mathrm{~kg}$ tension before it breaks.

\subsubsection{Tear Index}

Tearing resistance of paper samples was analyzed by a tearing strength tester $(\mathrm{Ku}-$ magai Riki Kogyo Co., Ltd., Tokyo, Japan) according to TAPPI T 414 om-12 (Elmendorf method) [28]. Test specimens were prepared in rectangular size of $6.3 \mathrm{~cm} \times 10 \mathrm{~cm}$. The tear resistance force $(\mathrm{N})$ was recorded and then calculated the tear index according to the following Equation (4):

$$
\text { Tear index }\left(\mathrm{mN} \cdot \mathrm{m}^{2} / \mathrm{g}\right)=[9.807 \times \text { tear resistance }] / \text { basis weight }
$$

\subsubsection{Burst Index}

Burst index was determined using a Mullen bursting strength tester (Kumagai Riki Kogyo Co. Ltd., Tokyo, Japan) according to TAPPI T 403 om-15 [29] A rectangular paper sample ( $12.5 \mathrm{~cm} \times 12.5 \mathrm{~cm}$ in size) was clamped firmly between two steel annular plates. A rubber diaphragm under one plate was pressurized by a fluid, causing the diaphragm to bulge. The pressure was increased at a constant rate until the bulging diaphragm caused the paper sheet to rupture. A pressure gauge on the instrument provided a measure of the bursting pressure needed to rupture the paper. Bursting strength was reported in kilopascals ( $\mathrm{kPa}$ ) and then the burst index was calculated using following Equation (5):

$$
\text { Burst index }\left(\mathrm{kPa} \cdot \mathrm{m}^{2} / \mathrm{g}\right)=\text { burst strength } / \text { basis weight }
$$

\subsection{Soil Burial Biodegradability Test}

The soil biodegradation study was performed in laboratory scale following a method described by [30] with some modifications. The paper samples were cut in specimens with the size of $2.5 \mathrm{~cm} \times 2.5 \mathrm{~cm}$ and dried in a hot air oven at $50{ }^{\circ} \mathrm{C}$ until a constant weight. Three replicates for each sample were buried into a commercial soil at 4-6 cm depth in a plastic box and left at $58{ }^{\circ} \mathrm{C}$ for 56 days. The distilled water was added at a certain level into the soil every 2-3 days to ensure the sufficient moisture during the test. The samples were removed from the soil for every 7 days, brushed softly, washed several times with distilled water and then dried at $50^{\circ} \mathrm{C}$ until a constant weight. The degree of degradation of paper samples were calculated by normalizing the paper sample weight at different days of incubation respect to the initial value by using following Equation (6):

$$
\text { Degree of degradation }(\%)=\left[\left(\mathrm{m}_{\mathrm{i}}-\mathrm{m}_{\mathrm{r}}\right) / \mathrm{m}_{\mathrm{i}}\right] \times 100
$$

where $m_{i}=$ the initial weight of the dry sample; $m_{r}=$ the weight of the dry sample after the test. 


\subsection{Water Drop Penetration Test}

Water drop penetration test of paper samples were revealed by followed the standard method of TAPPI T $835 \mathrm{om}-14$ [31] with some modification. One droplet of distilled water $(10 \mu \mathrm{L})$ was dropped on surface of a square paper samples $(2.5 \mathrm{~cm} \times 2.5 \mathrm{~cm})$ using an autopipette and counting the time, in which the drop of water was whole absorbed by the papers.

\subsection{Statistical Analysis}

All experiment data were calculated from at least 9 replicate and expressed as mean \pm SD. Analysis of variance (ANOVA) was performed by Duncan's multiple-range test (DMRT) using the SPSS software (SPSS for Windows, SPSS Inc., Chicago, IL, USA) at $p \leq 0.05$.

\section{Results and Discussion}

\subsection{Characteristics of Biosynthesized P(3-HB)}

The Rhodococcus pyridinivorans BSRT1-1, a rare actinomyces strain, produced high yield of $\mathrm{P}(3-\mathrm{HB})(46.8 \pm 2.0 \%$ based on dry cell weight) in a $10 \mathrm{~L}$ bioreactor under the optimum condition previously published by our research group [22]. In this study, gel permeation chromatography (GPC) was used to evaluate the molecular weight of $\mathrm{P}(3-\mathrm{HB})$ to understand the general characteristics of the $\mathrm{P}(3-\mathrm{HB})$ polymer. Owing to the molecular weight and molecular weight distribution of polymers, it plays a critical role in regards to end-use product properties of polymers including strength, toughness, flow properties, shear viscosity and elasticity [32,33]. It has been demonstrated that the average molecular weight of $\mathrm{P}(3-\mathrm{HB})$ depended on several factors such as bacterial strains, medium composition and carbon sources, a fermented condition and the downstream process [34]. The weight $\left(M_{\mathrm{W}}\right)$ and number ( $M$ Hitachi SU8020, Krefeld, Germany) -average molecular weight and respective polydispersity index (PDI) $\left(M_{\mathrm{w}} / M_{\mathrm{n}}\right)$ of the $\mathrm{P}(3-\mathrm{HB})$ were $6.07 \times 10^{5} \mathrm{~g} / \mathrm{mol}, 2.96 \times 10^{5} \mathrm{~g} / \mathrm{mol}$ and 2 , respectively. The PDI reflects the degree of heterogeneity of the polymer's chain lengths. Hence, the $\mathrm{P}(3-\mathrm{HB})$ showed the acceptable heterogenous because the PDI of $\mathrm{P}(3-\mathrm{HB})$ produced by wild-type bacteria is usually about 2.0 [35]. Table 1 shows the comparison among the average molecular weight $\left(M_{\mathrm{w}}, M_{\mathrm{n}}\right)$ and PDI of the $\mathrm{P}(3-\mathrm{HB})$ synthesized in this study and other studies. The average molecular weight of $\mathrm{P}(3-\mathrm{HB})$ synthesized in this study resembled the $\mathrm{P}(3-\mathrm{HB})$ produced by $R$. equi [23] and Bacillus subtilis MSBN17 [36]; all of them had average molecular weight lower than $10^{6} \mathrm{~g} / \mathrm{mol}$, indicating the acceptable molecular weight of $\mathrm{P}(3-\mathrm{HB})$ and qualifying for commercial application [37].

\subsection{Physical and Color Properties of P(3-HB) Non-Coated and Coted Pineapple Leaf Fiber Papers (PLFP)}

The thickness of PLFP did not change with increasing of commercial P(3-HB) concentrations, whereas the weight $(\mathrm{g})$ and basis weight $\left(\mathrm{g} / \mathrm{m}^{2}\right)$ of the commercial $\mathrm{P}(3-\mathrm{HB})$ coated PLFPs at 7.5 and $10 \%(w / v)$ were significantly increased $(p \leq 0.05)$. The colorimetric parameters of non-coated and coated PLFP are presented in Table 2. The coating of $\mathrm{P}(3-\mathrm{HB})$ significantly improved lightness $\left(L^{*}\right)$ and brightness of PLFP $(p \leq 0.05)$, while the redness $\left(+a^{*}\right)$ and the yellowness $\left(+b^{*}\right)$ of the commercial P(3-HB) coated PLFP was slightly lower than those of the non-coated PLFP (Table 3). By comparing the commercial P(3-HB) to the biosynthesized $\mathrm{P}(3-\mathrm{HB})$ on coating of PLFP at $7.5 \%(w / v)$, the weight $(\mathrm{g})$, basis weight $\left(\mathrm{g} / \mathrm{m}^{2}\right)$ and percentage of increasing in weight of both coated PLFP was shown to be non-significantly different. The lightness $\left(L^{*}\right)$ of biosynthesized P(3-HB) coated PLFP was slightly lower, but the brightness was significantly higher than that of the commercial P(3-HB) coated PLFP (Table 3). Moreover, high concentration of commercial P(3-HB) had a slightly increasing effect on the total color difference $\left(\Delta E^{*}\right)$ of the commercial $\mathrm{P}(3-\mathrm{HB})$ coated PLFP, while the biosynthesized $\mathrm{P}(3-\mathrm{HB})$ showed the lowest $\Delta E^{*}$ compared to the non- 
coated PLFP (Table 3). This clearly indicated that P(3-HB) synthesized in this study could enhance the brightness of PLFP attributed to the whiteness nature of $\mathrm{P}(3-\mathrm{HB})$ polymer.

Table 1. The weight $\left(M_{\mathrm{W}}\right)$ and number $\left(M_{\mathrm{n}}\right)$-average molecular weight and respective polydispersity index $(\mathrm{PDI})\left(M_{\mathrm{w}} / M_{\mathrm{n}}\right)$ of the $\mathrm{P}(3-\mathrm{HB})$ produced by R. pyridinivorans BSRT-1, and comparison with other reports.

\begin{tabular}{cccccc}
\hline $\begin{array}{c}\text { Polymer/Carbon } \\
\text { Source }\end{array}$ & Bacterial Strains & $\begin{array}{c}\boldsymbol{M}_{\mathbf{w}} \\
(\mathbf{g} / \mathbf{m o l})\end{array}$ & $\begin{array}{c}\boldsymbol{M}_{\mathbf{n}} \\
(\mathbf{g} / \mathbf{m o l})\end{array}$ & $\begin{array}{c}\text { PDI } \\
\left(\boldsymbol{M}_{\mathbf{w}} / \mathbf{M}_{\mathbf{n}}\right)\end{array}$ & References \\
\hline $\mathrm{P}(3-\mathrm{HB})$ (fructose) & $\begin{array}{c}\text { R. pyridinivorans } \\
\text { BSRT1-1 }\end{array}$ & $6.07 \times 10^{5}$ & $2.96 \times 10^{5}$ & 2.0 & This study \\
\hline $\begin{array}{c}\text { Commercial } \\
\text { P(3-HB) }\end{array}$ & - & $5.05 \times 10^{5}$ & - & - & This study \\
\hline $\begin{array}{c}\text { PHB (crude palm } \\
\text { kernel oil) }\end{array}$ & R. equi & $6.42 \times 10^{5}$ & $3.73 \times 10^{5}$ & 1.72 & {$[23]$} \\
\hline PHB (soy) & Cupriavidis necator & $7.90 \times 10^{5}$ & $3.49 \times 10^{5}$ & 2.26 & {$[38]$} \\
\hline $\begin{array}{c}\text { PHB (molasses and } \\
\text { corn steep liquor) }\end{array}$ & $\begin{array}{c}\text { Bacillus megaterium } \\
\text { ATCC 6748 }\end{array}$ & $3.90 \times 10^{6}$ & $2.65 \times 10^{6}$ & 1.47 & {$[39]$} \\
\hline $\begin{array}{c}\text { PHB (pulp } \\
\text { industry waste) }\end{array}$ & $\begin{array}{c}\text { Bacillus } \\
\text { subtilis MSBN17 }\end{array}$ & $6.40 \times 10^{5}$ & $3.80 \times 10^{5}$ & 1.68 & {$[36]$} \\
\hline $\begin{array}{c}\text { P(3HB-co-3HV) } \\
\text { (bagasse extract) }\end{array}$ & $\begin{array}{c}\text { Halomonas } \\
\text { campisalis }\end{array}$ & $1.39 \times 10^{6}$ & $8.39 \times 10^{5}$ & 1.66 & {$[40]$} \\
\hline
\end{tabular}

Table 2. Physical properties of the non-coated PLFP, the commercial P(3-HB) coated PLFPs at 5, 7.5 and $10 \%(w / v)$ and the biosynthesized P(3-HB) coated PLFP at 7.5\% $(w / v)$.

\begin{tabular}{|c|c|c|c|c|c|}
\hline \multirow{2}{*}{ Properties } & \multirow{2}{*}{ Non-Coated PLFP } & \multicolumn{3}{|c|}{ Commercial P(3-HB) } & \multirow{2}{*}{$\begin{array}{c}\begin{array}{c}\text { Biosynthesized } \\
\mathrm{P}(3-\mathrm{HB})\end{array} \\
7.5 \% \\
\end{array}$} \\
\hline & & $5 \%$ & $7.5 \%$ & $10 \%$ & \\
\hline Weight (g) & $1.55 \pm 0.19^{b}$ & $1.79 \pm 0.26^{b}$ & $2.35 \pm 0.50^{a}$ & $2.62 \pm 0.47^{\mathrm{a}}$ & $2.50 \pm 0.06^{\mathrm{a}}$ \\
\hline Basic weight $\left(\mathrm{g} / \mathrm{m}^{2}\right)$ & $99.64 \pm 12.73^{b}$ & $114.35 \pm 16.56^{b}$ & $150.09 \pm 31.88^{a}$ & $171.30 \pm 30.02^{a}$ & $159.82 \pm 3.73^{a}$ \\
\hline $\begin{array}{c}\text { The percentage } \\
\text { increase in weight }(\%)\end{array}$ & - & $60.81 \pm 16.04^{b}$ & $64.69 \pm 16.17^{b}$ & $98.78 \pm 12.13^{a}$ & $59.62 \pm 7.64^{b}$ \\
\hline Thickness (mm) & $0.27 \pm 0.05^{b}$ & $0.29 \pm 0.05^{b}$ & $0.29 \pm 0.06^{b}$ & $0.27 \pm 0.03^{b}$ & $0.59 \pm 0.01^{a}$ \\
\hline
\end{tabular}

Different letters $(a, b)$ in the same row mean that the results are significantly different at $p \leq 0.05$, while ns means that the results are not significantly different at $p>0.05$ by Duncan's multiple-range test.

\subsection{Scanning Electron Microscopy (SEM)}

The SEM micrograph of the surface and cross section of the non-coated PLFP and the commercial or P(3-HB) coated PLFPs are illustrated in Figure 2. The non-coated PLFP showed the disordered entanglements of pineapple fibers network to have many pores, whereas the coted PLFPs (with commercial or biosynthesized P(3-HB)) showed a smooth layer of $\mathrm{P}(3-\mathrm{HB})$ covering the entire surface of PLFPs with no visible pores, which was clearly contrast with the fibrous network of the non-coated PLFP. It was observed that some amount of $\mathrm{P}(3-\mathrm{HB})$ embedded to the pineapple fibers on surface of PLFPs. For cross section, the commercial $\mathrm{P}(3-\mathrm{HB})$ and $\mathrm{P}(3-\mathrm{HB})$ coated PLFP showed a compact structure of $\mathrm{P}(3-\mathrm{HB})$ on top surface of PLFPs, while the non-coated PLFP showed a fibrous layer. This result confirmed that both the commercial and biosynthesized $\mathrm{P}(3-\mathrm{HB})$ could be well coated all over the PLFP surface via the dip-coating techniques. 
Table 3. Colorimetric parameters of the non-coated PLFP, the commercial P(3-HB) coated PLFPs at 5, 7.5 and $10 \%(w / v)$ and the biosynthesized P(3-HB) coated PLFP at 7.5\% $(w / v)$.

\begin{tabular}{cccccc}
\hline \multirow{2}{*}{$\begin{array}{c}\text { Color Pa- } \\
\text { rameters }\end{array}$} & $\begin{array}{c}\text { Non-Coated } \\
\text { PLFP }\end{array}$ & \multicolumn{3}{c}{ Commercial P(3-HB) } & $\begin{array}{c}\text { Biosynthesized } \\
\text { P(3-HB) }\end{array}$ \\
\cline { 3 - 6 } & & $\mathbf{5 \%}$ & $\mathbf{7 . 5 \%}$ & $\mathbf{1 0 \%}$ & $\mathbf{7 . 5 \%}$ \\
\hline$L^{*}$ & $87.92 \pm 0.89^{\mathrm{b}}$ & $91.22 \pm 0.35^{\mathrm{a}}$ & $91.23 \pm 0.33^{\mathrm{a}}$ & $91.23 \pm 0.39^{\mathrm{a}}$ & $87.63 \pm 0.22^{\mathrm{b}}$ \\
\hline$a^{*}$ & $1.23 \pm 0.04^{\mathrm{a}}$ & $0.86 \pm 0.15^{\mathrm{c}}$ & $1.00 \pm 0.12^{\mathrm{b}}$ & $0.86 \pm 0.06^{\mathrm{c}}$ & $1.01 \pm 0.02^{\mathrm{b}}$ \\
\hline$b^{*}$ & $9.21 \pm 0.09^{\mathrm{a}}$ & $6.91 \pm 0.28^{\mathrm{b}}$ & $7.17 \pm 0.47^{\mathrm{b}}$ & $7.11 \pm 0.39^{\mathrm{b}}$ & $8.16 \pm 0.02^{\mathrm{b}}$ \\
\hline$\Delta E^{*}$ & - & $4.03 \pm 0.07^{\mathrm{b}}$ & $6.14 \pm 0.17^{\mathrm{a}}$ & $6.32 \pm 0.36^{\mathrm{a}}$ & $1.03 \pm 0.25^{\mathrm{c}}$ \\
\hline $\begin{array}{c}\text { Brightness } \\
(\%)\end{array}$ & $27.39 \pm 0.60^{\mathrm{c}}$ & $41.98 \pm 13.40^{\mathrm{b}}$ & $44.06 \pm 2.38^{\mathrm{b}}$ & $45.13 \pm 1.59^{\mathrm{b}}$ & $62.57 \pm 0.60^{\mathrm{a}}$
\end{tabular}

Different letters $(\mathrm{a}, \mathrm{b}, \mathrm{c})$ in the same row mean that the results are significantly different at $p \leq 0.05$ by Duncan's multiple-range test.
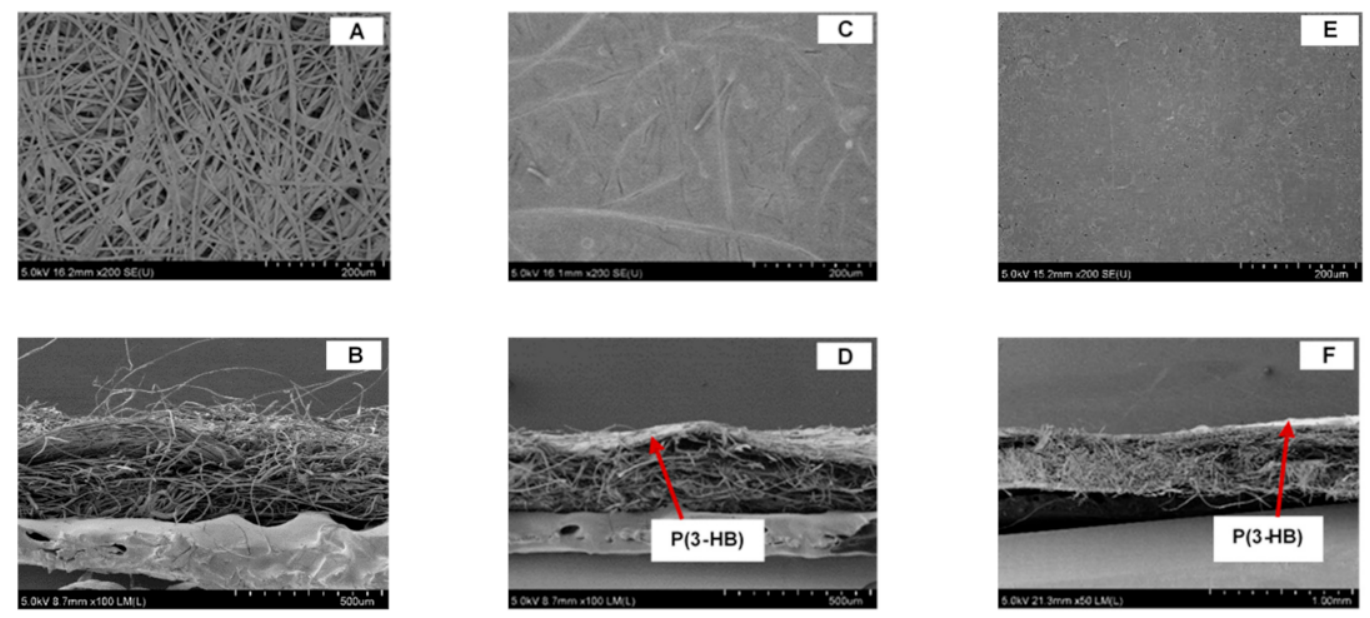

Figure 2. SEM micrographs of the surface and cross section of $(\mathbf{A}, \mathbf{B})$ the non-coated PLFP, $(\mathbf{C}, \mathbf{D})$ the commercial $\mathrm{P}(3-\mathrm{HB})$ coated PLFP at 7.5\% $(w / v)$ and $(\mathbf{E}, \mathbf{F})$ the biosynthesized P(3-HB) coated PLFP at $7.5 \%(w / v)$.

\subsection{Fourier Transform Infrared Spectroscopy (FTIR)}

Chemical structure of $\mathrm{P}(3-\mathrm{HB})$ non-coated and coated PLFPs were studied by Fourier transform infrared spectroscopy (FTIR), and the FTIR spectra are shown in Figure 3. The spectra of PLFP showed the peak at $3380 \mathrm{~cm}^{-1}$ which is attributed to the absorption of hydroxyl groups $(\mathrm{OH}-)$. While the commercial and biosynthesized $\mathrm{P}(3-\mathrm{HB})$ showed the characteristic bands located at $1718-1720 \mathrm{~cm}^{-1}$ assigned to the ester carbonyl groups $(\mathrm{C}=\mathrm{O})$, the band at $1043-1054 \mathrm{~cm}^{-1}$ was assigned to $\mathrm{C}-\mathrm{O}$ ester bond stretching. Other bands located at $1268-1282 \mathrm{~cm}^{-1}$ were assigned to methylene group $\left(-\mathrm{CH}_{2}\right)$ and the band at $1382-1386 \mathrm{~cm}^{-1}$ was associated with methyl group $\left(-\mathrm{CH}_{3}\right)$ [15]. The spectra of $\mathrm{P}(3-\mathrm{HB})$ non-coated and coated PLFPs were similar to the characteristic of $\mathrm{P}(3-\mathrm{HB})$ with a slight reduction of hydroxyl group at the band of $3380 \mathrm{~cm}^{-1}$. The FTIR result indicated that the film of commercial and biosynthesized $\mathrm{P}(3-\mathrm{HB})$ was well generated by the dip-coating technique over the entire surface of PLFP. 


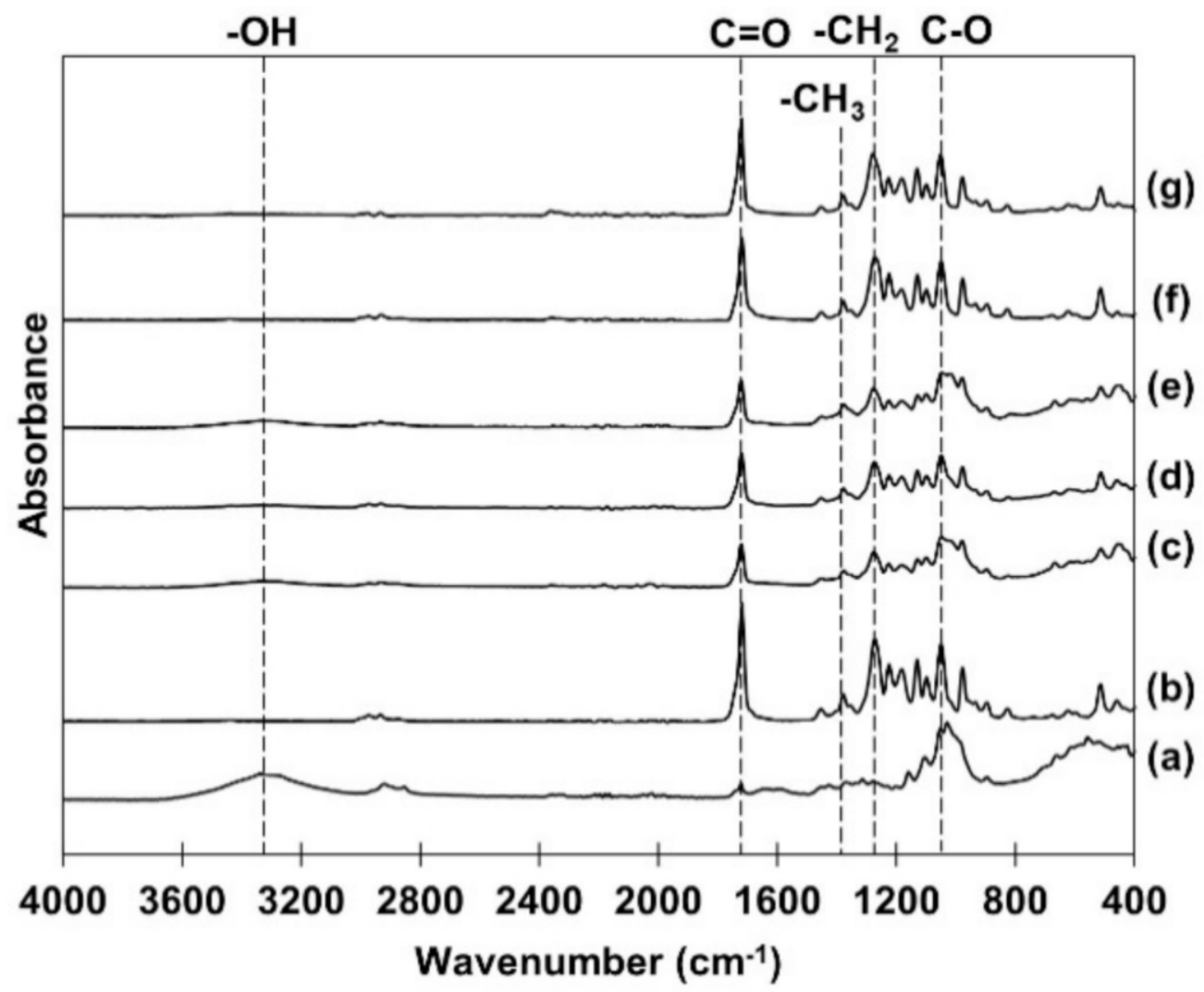

Figure 3. FTIR spectra of (a) non-coated PLFP, (b) commercial P(3-HB) film, (c-e) commercial P(3-HB) coated PLFPs at 5\%, 7.5\% and 10\% (w/v), (f) biosynthesized P(3-HB) film and (g) biosynthesized $\mathrm{P}(3-\mathrm{HB})$ coated PLFP at $7.5 \%(w / v)$.

\subsection{Mechanical Properties}

The effect of commercial $\mathrm{P}(3-\mathrm{HB})$ contents $(5,7.5$ and $10 \%(w / v))$ on mechanical properties of coated PLFP is shown in Figure 4. It was found that coating of commercial $\mathrm{P}(3-\mathrm{HB})$ did not affect the tensile index of PLFP. The percentage of elongation, tear index and burst index of the commercial $\mathrm{P}(3-\mathrm{HB})$ coated PLFP were significantly reduced. As it is well known that $\mathrm{P}(3-\mathrm{HB})$ is a brittle biopolymer due to its high degree of crystallinity, this result might therefore be influenced by the matrix of commercial $\mathrm{P}(3-\mathrm{HB})$ retained in the internal porous space of PLFPs after the coating process which resulted in an increased brittleness of the coated papers [41]. On the contrary, the folding endurance of commercial $\mathrm{P}(3-\mathrm{HB})$ coated PLFP was significantly increased compared with the non-coated PLFP $(p \leq 0.05)$. This increase of folding endurance might be associated with the extra coating weight on the surface of the coated paper which resulted in the resistance to the repeated folding test [42]. The biosynthesized P(3-HB) coated PLFP at 7.5\% $(w / v)$ was significantly higher in tensile index, percentage of elongation, folding endurance and burst index than that of the commercial $\mathrm{P}(3-\mathrm{HB})$ coated PLFP at all $\mathrm{P}(3-\mathrm{HB})$ concentrations and the noncoated PLFP $(p \leq 0.05)$. Tear index of the biosynthesized P(3-HB) coated PLFP was similar to the commercial $\mathrm{P}(3-\mathrm{HB})$ coated PLFP at 5 and $7.5 \%(w / v)$. It is remarkable that both the commercial $\mathrm{P}(3-\mathrm{HB})$ and biosynthesized $\mathrm{P}(3-\mathrm{HB})$ coated papers showed lower tear index than that of the non-coated paper. This might be due to the matrix of $\mathrm{P}(3-\mathrm{HB})$ which decreased the inter-fiber bonding of papers and resulted in the decreased tear index of coated papers [43]. An improvement on mechanical properties of the $\mathrm{P}(3-\mathrm{HB})$ coated papers might be explained in term of the difference of average molecular weight between the commercial and biosynthesized $\mathrm{P}(3-\mathrm{HB})$. 


\subsection{Water Drop Penetration}

Water drop penetration test of non-coated and coted PLFPs were performed by the detection of water drop penetration time (second) on the surface of non-coated and coated PLFPs (Figure 5.). The result showed that the water drop was suddenly absorbed by the non-coated PLFP, which then resulted in the lowest water drop penetration time $(0 \mathrm{~s})$. Water drop penetration time of the commercial $\mathrm{P}(3-\mathrm{HB})$ coated PLFPs were significantly increased when compared to the non-coated PLFP, especially for high commercial $\mathrm{P}(3-\mathrm{HB})$ contents at 7.5 and $10 \%(w / v)$, which were higher than that of non-coated PLFP for 18 and 26 times, respectively. In addition, the water drop penetration time of biosynthesized $\mathrm{P}(3-\mathrm{HB})$ coated PLFP was close to that of the commercial P(3-HB) coated PLFP. This result clearly demonstrated that hydrophobic $\mathrm{P}(3-\mathrm{HB})$ could delay water absorption on PLFP surfaces.
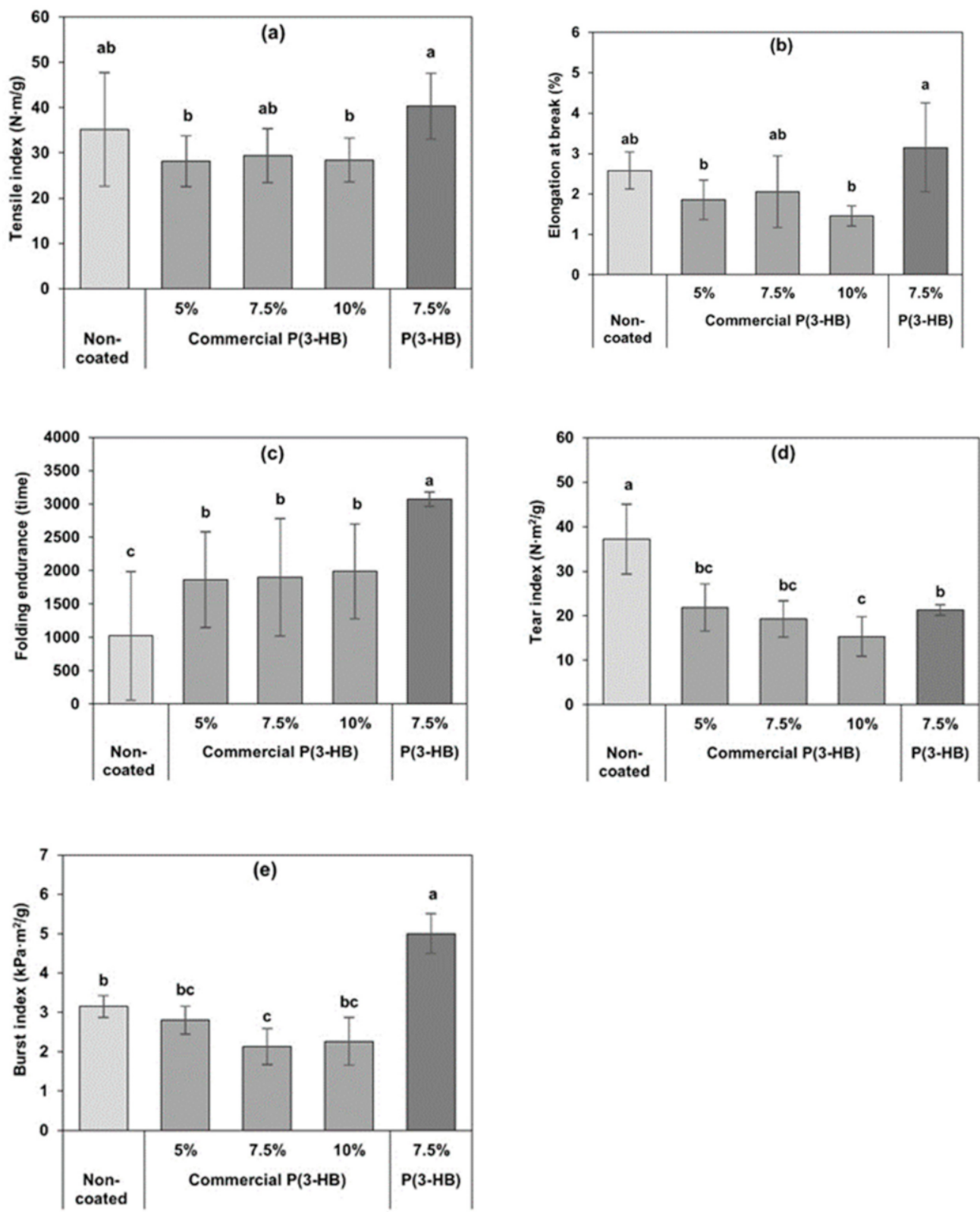

Figure 4. Mechanical properties of the non-coated PLFP, the commercial P(3-HB) coated PLFPs at 5\%, $7.5 \%$ and $10 \%(w / v)$ and the biosynthesized P(3-HB) coated PLFP at 7.5\% (w/v) including (a) tensile index, (b) elongation, (c) folding endurance, (d) tear index and (e) burst index. Different letters above graph bars re represent the different between the averages of each parameter at significance level of $p \leq 0.05$. 


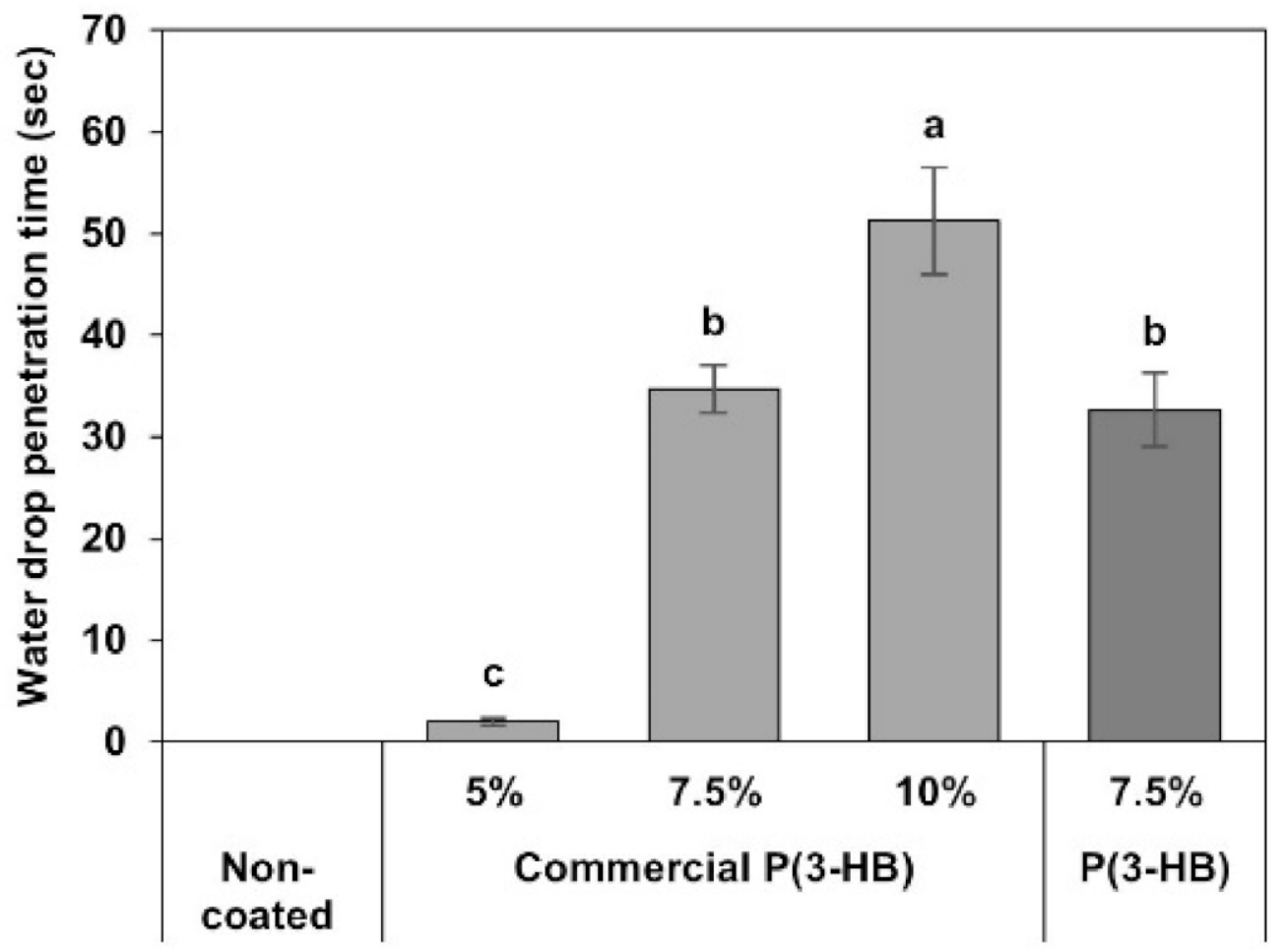

Figure 5. Water drop penetration time on surface of the non-coated PLFP, the commercial P(3-HB) coated PLFPs at $5 \%, 7.5 \%$ and $10 \%(w / v)$ and the biosynthesized P(3HB) coated PLFP at $7.5 \%(w / v)$. Different letters above graph bars are represent the different between the averages of each parameter at significance level of $p \leq 0.05$.

\subsection{Soil Burial Biodegradability}

The coated PLFPs, having predominant mechanical properties and acceptable water drop penetration time, were selected to evaluate and compare the biodegradability. The biosynthesized $\mathrm{P}(3-\mathrm{HB})$ coated PLFP with varying contents $(0 \%, 5 \%, 7.5 \%$ and $10 \%(w / v))$ were buried into the moist soil for a period of 56 days at $63^{\circ} \mathrm{C}$. The visual appearance of degraded paper samples recovered at different testing times are presented in Figure 6. It was observed that the residual samples at 49 and 56 days were darker and more fragile, as could be seen in non-coated PLFP and PLFP coated with $5 \%$ and $7.5 \%(w / v)$ of $\mathrm{P}(3-\mathrm{HB})$. In addition, it was noticeable that increasing of $\mathrm{P}(3-\mathrm{HB})$ content to $10 \%(w / v)$ decelerated the degree of degradation of the coated paper ( $42 \%$ after 56 days), while the non-coated and $\mathrm{P}(3-\mathrm{HB})$ coated PLFP at $5 \%$ and $7.5 \%(w / v)$ showed higher degree of degradation around $53-60 \%$ after 56 days (Figure 7.). This result might be due to the high amount of crystalline $\mathrm{P}(3-\mathrm{HB})$, which slowed down the degradation phenomenon [44]. However, the rate of biodegradation of biocomposites depends on many environmental factors such as moisture, light (radiation), temperature and microorganisms [45]. Among these factors, $\mathrm{P}(3-\mathrm{HB})$ degradation is mainly enzymatically degraded by various kinds of microorganisms existing in natural soils [46]. Thus, the microbial communities in soil, which are responsible for biodegradation of the $\mathrm{P}(3-\mathrm{HB})$ coated PLFP should be evaluated for further study. 


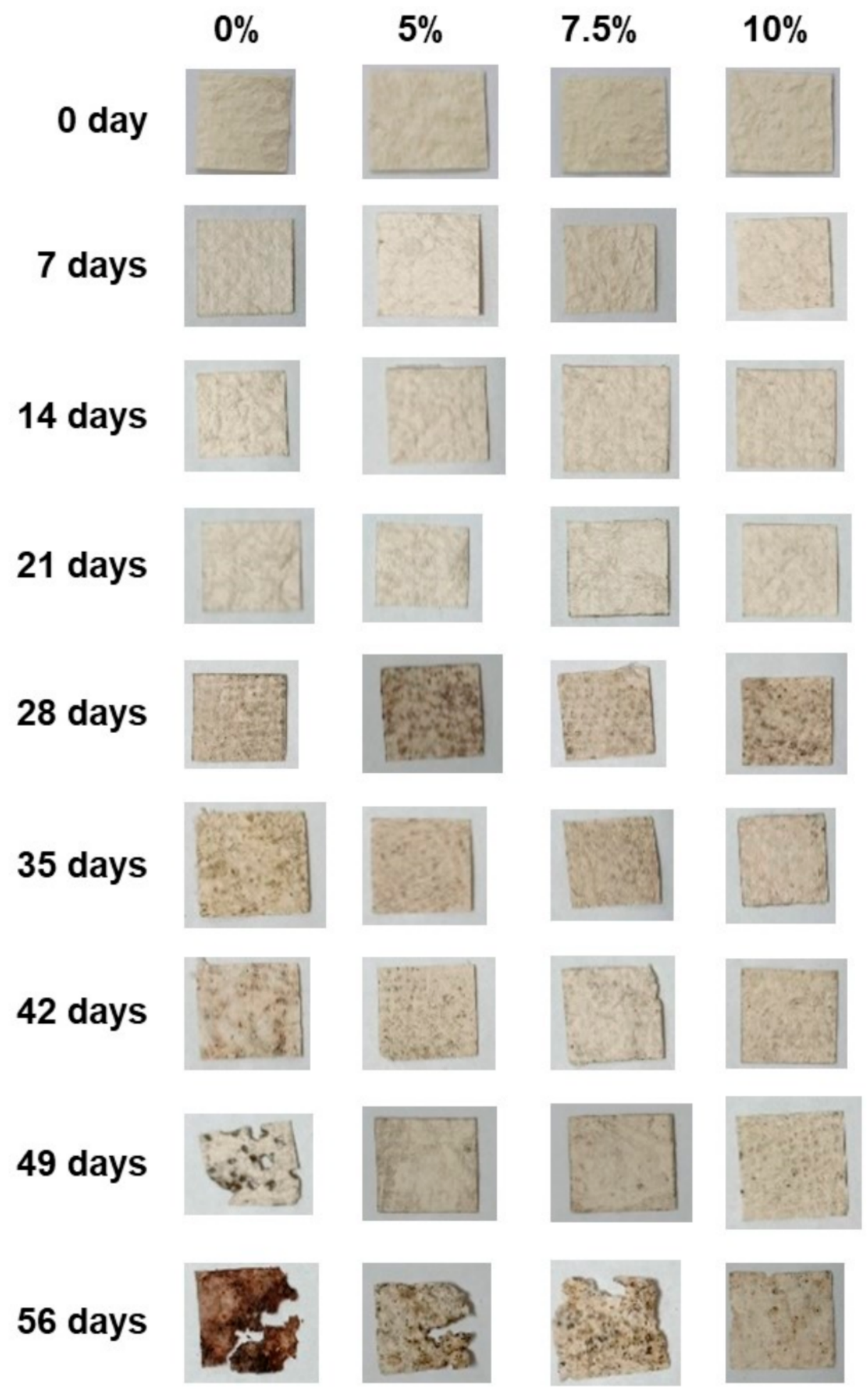

Figure 6. Visual appearance of non-coated and biosynthesized $\mathrm{P}(3-\mathrm{HB})$ coated PLFPs $(5 \%, 7.5 \%$ and $10 \%(w / v))$ at different times after burial in soil. 


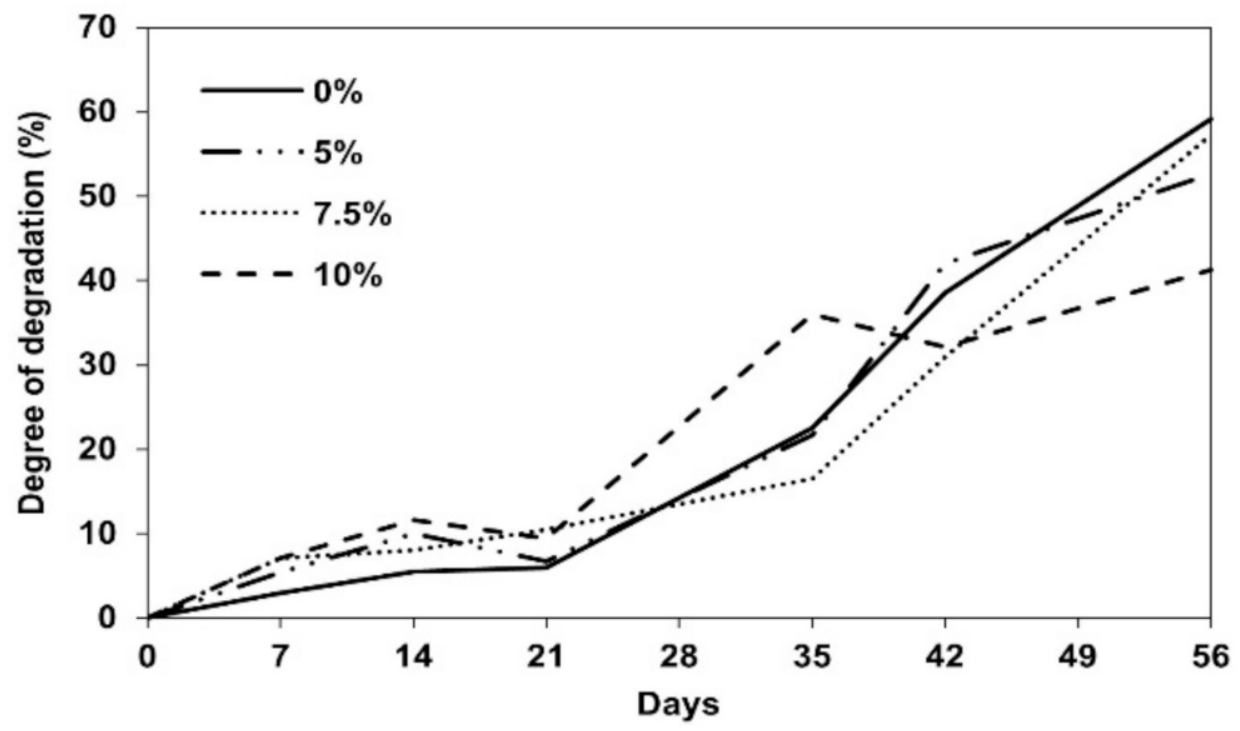

Figure 7. Degree of degradation of non-coated and biosynthesized P(3-HB) coated PLFPs (5\%, 7.5\% and $10 \%(w / v))$ at different days of soil burial biodegradability test.

\section{Conclusions}

This study applied the utilization of the poly(3-hydroxybutyrate) $(\mathrm{P}(3-\mathrm{HB}))$ produced by $R$. pyridinivorans BSRT1-1, a highly potential $\mathrm{P}(3-\mathrm{HB})$ producing bacterium, for dipcoating on pineapple leaf fiber paper (PLFP). It resulted in an improvement of brightness and mechanical properties (tensile index, percentage of elongation, folding endurance and burst index) of PLFPs over that of a commercial P(3-HB) coated and non-coated PLFP. SEM and FTIR studies confirmed that $\mathrm{P}(3-\mathrm{HB})$ completely covered the surface of PLFP. This $\mathrm{P}(3-\mathrm{HB})$ coated PLFP showed an increase of water drop penetration time compared to the non-coated PLFP, indicating that the $\mathrm{P}(3-\mathrm{HB})$ could reduce the water susceptibility of the cellulose of PLFP. Moreover, soil burial biodegradation of the P(3-HB) coated PLFPs occurred rapidly within 56 days. According to these results, the biosynthesized $\mathrm{P}(3-\mathrm{HB})$ has the potential as an eco-friendly material for paper coating application to replace the non-renewable polymers.

Author Contributions: Conceptualization, P.V., K.S. and R.C.; methodology, K.K., J.B. and C.T.; formal analysis, K.K. and R.C.; investigation, P.V. and R.C.; data curation, K.K., J.B. and C.T.; writingoriginal draft preparation, P.V., K.K., A.J. and R.C.; writing-review and editing, P.V., A.J. and R.C.; visualization, K.K.; supervision, P.V. and R.C.; project administration and funding acquisition, P.V. All authors have read and agreed to the published version of the manuscript.

Funding: This research was funded by Kasetsart University Research and Development Institute (KURDI), Kasetsart University, Bangkok, Thailand. The authors are grateful to the Specialized Center of Rubber and Polymer Materials in Agriculture and Industry (RPM), Faculty of Science, Kasetsart University, Bangkok, Thailand for publication support.

Institutional Review Board Statement: Not applicable.

Informed Consent Statement: Not applicable.

Data Availability Statement: Data is contained within the article.

Acknowledgments: The authors are grateful to the Kasetsart University Research and Development Institute (KURDI) for supporting this research and the Specialized Center of Rubber and Polymer Materials in Agriculture and Industry (RPM), Faculty of Science, Kasetsart University, Bangkok, Thailand for partly supporting publication charge.

Conflicts of Interest: The authors declare no conflict of interest. 


\section{References}

1. Laftah, W.A.; Wan Abdul Rahman, W.A. Pulping process and the potential of using non-wood pineapple leaves fiber for pulp and paper production: A review. J. Nat. Fibers 2015, 13, 85-102. [CrossRef]

2. Todkar, S.S.; Patil, S.A. Review on mechanical properties evaluation of pineapple leaf fibre (PALF) reinforced polymer composites. Compos. B Eng. 2019, 174, 106927. [CrossRef]

3. Chollakup, R.; Tantatherdtam, R.; Ujjin, S.; Sriroth, K. Pineapple leaf fiber reinforced thermoplastic composites: Effects of fiber length and fiber content on their characteristics. J. Appl. Polym. Sci. 2011, 119, 1952-1960. [CrossRef]

4. Smitthipong, W.; Tantatherdtam, R.; Chollakup, R. Effect of pineapple leaf fiber-reinforced thermoplastic starch/poly(lactic acid) green composite. J. Thermoplast. Compos. Mater. 2013, 28, 717-729. [CrossRef]

5. Suwanruji, P.; Tuechart, T.; Smitthipong, W.; Chollakup, R. Modification of pineapple leaf fiber surfaces with silane and isocyanate for reinforcing thermoplastic. J. Thermoplast. Compos. Mater. 2016, 30, 1344-1360. [CrossRef]

6. Chollakup, R.; Askanian, H.; Delor-Jestin, F. Initial properties and ageing behaviour of pineapple leaf and palm fibre as reinforcement for polypropylene. J. Thermoplast. Compos. Mater. 2016, 30, 174-195. [CrossRef]

7. Sibaly, S.; Jeetah, P. Production of paper from pineapple leaves. J. Environ. Chem. Eng. 2017, 5, 5978-5986. [CrossRef]

8. Simona, J.; Dani, D.; Petr, S.; Marcela, N.; Jakub, T.; Bohuslava, T. Edible films from carrageenan/orange essential oil/trehalosestructure, optical properties, and antimicrobial activity. Polymers 2021, 13, 332. [CrossRef]

9. Khwaldia, K.; Arab-Tehrany, E.; Desobry, S. Biopolymer coatings on paper packaging materials. Compr. Rev. Food Sci. Food Saf. 2010, 9, 82-91. [CrossRef]

10. Rastogi, V.K.; Samyn, P. Bio-based coatings for paper applications. Coatings 2015, 5, 887-930. [CrossRef]

11. Pena, C.; Castillo, T.; Garcia, A.; Millan, M.; Segura, D. Biotechnological strategies to improve production of microbial poly-(3hydroxybutyrate): A review of recent research work. Microb. Biotechnol. 2014, 7, 278-293. [CrossRef]

12. Kalia, V.C.; Singh Patel, S.K.; Shanmugam, R.; Lee, J.K. Polyhydroxyalkanoates: Trends and advances toward biotechnological applications. Bioresour. Technol. 2021, 326, 124737. [CrossRef] [PubMed]

13. Ragaert, P.; Buntinx, M.; Maes, C.; Vanheusden, C.; Peeters, R.; Wang, S.; D’Hooge, D.R.; Cardon, L. Polyhydroxyalkanoates for Food Packaging Applications. In Reference Module in Food Science; Elsevier: Amsterdam, The Netherlands, 2019.

14. Obeso, C.G.; Sousa, M.P.; Song, W.; Rodriguez-Pérez, M.A.; Bhushan, B.; Mano, J.F. Modification of paper using polyhydroxybutyrate to obtain biomimetic superhydrophobic substrates. Colloids Surf. Physicochem. Eng. Aspects 2013, 416, 51-55. [CrossRef]

15. Cyras, V.P.; Soledad, C.M.; Analía, V. Biocomposites based on renewable resource: Acetylated and non acetylated cellulose cardboard coated with polyhydroxybutyrate. Polymer 2009, 50, 6274-6280. [CrossRef]

16. Cyras, V.P.; Commisso, M.S.; Mauri, A.N.; Vázquez, A. Biodegradable double-layer films based on biological resources: Polyhydroxybutyrate and cellulose. J. Appl. Polym. Sci. 2007, 106, 749-756. [CrossRef]

17. Anbukarasu, P.; Sauvageau, D.; Elias, A. Tuning the properties of polyhydroxybutyrate films using acetic acid via solvent casting. Sci. Rep. 2015, 5, 17884. [CrossRef]

18. Kuusipalo, J. PHB/V in extrusion coating of paper and paperboard: Part I: Study of functional properties. J. Polym. Environ. 2000, 8, 39-47. [CrossRef]

19. Seoane, I.T.; Manfredi, L.B.; Cyras, V.P. Bilayer biocomposites based on coated cellulose paperboard with films of polyhydroxybutyrate/cellulose nanocrystals. Cellulose 2018, 25, 2419-2434. [CrossRef]

20. Seoane, I.T.; Manfredi, L.B.; Cyras, V.P. Properties and processing relationship of polyhydroxybutyrate and cellulose biocomposites. Procedia Mater. Sci. 2015, 8, 807-813. [CrossRef]

21. Seoane, I.T.; Luzi, F.; Puglia, D.; Cyras, V.P.; Manfredi, L.B. Enhancement of paperboard performance as packaging material by layering with plasticized polyhydroxybutyrate/nanocellulose coatings. J. Appl. Polym. Sci. 2018, 135, 46872. [CrossRef]

22. Trakunjae, C.; Boondaeng, A.; Apiwatanapiwat, W.; Kosugi, A.; Arai, T.; Sudesh, K.; Vaithanomsat, P. Enhanced polyhydroxybutyrate (PHB) production by newly isolated rare actinomycetes Rhodococcus sp. strain BSRT1-1 using response surface methodology. Sci. Rep. 2021, 11, 1896. [CrossRef] [PubMed]

23. Altaee, N.; Fahdil, A.; Yousif, E.; Sudesh, K. Recovery and subsequent characterization of polyhydroxybutyrate from Rhodococcus equi cells grown on crude palm kernel oil. J. Taibah Univ. Sci. 2016, 10, 543-550. [CrossRef]

24. Chollakup, R.; Kongtud, W.; Sukatta, U.; Piriyasatits, K.; Premchookiat, M.; Jarerat, A. Development of rice straw paper coated with pomelo peel extract for bio-based and antibacterial packaging. Key Eng. Mater. 2020, 847, 141-146. [CrossRef]

25. TAPPI. Standards Brightness of Pulp, Paper, and Paperboard (Directional Reflectance at $457 \mathrm{~nm}$ ), Test Method. 2009. Available online: https:/ /imisrise.tappi.org/TAPPI/Products/01/T/0104T452.aspx (accessed on 19 January 2021).

26. TAPPI. Tensile Properties of Paper and Paperboard (Using Constant Rate of Elongation Apparatus), Test Method TAPPI/ANSI 2009. Available online: https://imisrise.tappi.org/TAPPI/Products/01/T/0104T494.aspx (accessed on 19 January 2021).

27. TAPPI. Folding Endurance of Paper (Schopper Type Tester), Test Method 2007. Available online: https://imisrise.tappi.org/ TAPPI/Products/01/T/0104T423.aspx (accessed on 19 January 2021).

28. TAPPI. Internal Tearing Resistance of Paper (Elmendorf-Type Method), Test Method. 2009. Available online: https://imisrise. tappi.org/TAPPI/Products/01/T/0104T414.aspx (accessed on 19 January 2021).

29. TAPPI. Bursting Strength of Paper, Test Method 2009. Available online: https://imisrise.tappi.org/TAPPI/Products/01/T/0104 T414.aspx (accessed on 19 January 2021). 
30. Seoane, I.T.; Manfredi, L.B.; Cyras, V.P.; Torre, L.; Fortunati, E.; Puglia, D. Effect of cellulose nanocrystals and bacterial cellulose on disintegrability in composting conditions of plasticized PHB nanocomposites. Polymers 2017, 9, 561. [CrossRef] [PubMed]

31. TAPPI. Water Absorption of Corrugating Medium: Water Drop Absoption Test, Test Method TAPPI/ANSI 2009. Available online: https://imisrise.tappi.org/TAPPI/Products/01/T/0104T835.aspx (accessed on 19 January 2021).

32. Penloglou, G.; Kretza, E.; Chatzidoukas, C.; Parouti, S.; Kiparissides, C. On the control of molecular weight distribution of polyhydroxybutyrate in Azohydromonas lata cultures. Biochem. Eng. J. 2012, 62, 39-47. [CrossRef]

33. Nunes, R.W.; Martin, J.R.; Johnson, J.F. Influence of molecular weight and molecular weight distribution on mechanical properties of polymers. Polym. Eng. Sci. 1982, 22, 205-228. [CrossRef]

34. McAdam, B.; Brennan Fournet, M.; McDonald, P.; Mojicevic, M. Production of polyhydroxybutyrate (PHB) and factors impacting its chemical and mechanical characteristics. Polymers 2020, 12, 2908. [CrossRef]

35. Fiorese, M.n.L.; Freitas, F.; Pais, J.; Ramos, A.M.; de Arag Ã£o, G.u.M.F.; Reis, M.A.M. Recovery of polyhydroxybutyrate (PHB) from Cupriavidus necator biomass by solvent extraction with 1,2-propylene carbonate. Eng. Life Sci. 2009, 9, 454-461. [CrossRef]

36. Sathiyanarayanan, G.; Saibaba, G.; Seghal Kiran, G.; Selvin, J. A statistical approach for optimization of polyhydroxybutyrate production by marine Bacillus subtilis MSBN17. Int. J. Biol. Macromol. 2013, 59, 170-177. [CrossRef]

37. Al-Battashi, H.; Annamalai, N.; Al-Kindi, S.; Nair, A.S.; Al-Bahry, S.; Verma, J.P.; Sivakumar, N. Production of bioplastic (poly3-hydroxybutyrate) using waste paper as a feedstock: Optimization of enzymatic hydrolysis and fermentation employing Burkholderia sacchari. J. Clean. Prod. 2019, 214, 236-247. [CrossRef]

38. Oliveira, F.C.; Dias, M.L.; Castilho, L.R.; Freire, D.M. Characterization of poly(3-hydroxybutyrate) produced by Cupriavidus necator in solid-state fermentation. Bioresour. Technol. 2007, 98, 633-638. [CrossRef] [PubMed]

39. Chaijamrus, S.; Udpuay, N. Production and Characterization of Polyhydroxybutyrate from Molasses and Corn Steep Liquor Produced by Bacillus megaterium ATCC 6748. Available online: https://cigrjournal.org/index.php/Ejounral/article/view/1216 (accessed on 19 January 2021).

40. Kulkarni, S.O.; Kanekar, P.P.; Jog, J.P.; Sarnaik, S.S.; Nilegaonkar, S.S. Production of copolymer, poly (hydroxybutyrate-cohydroxyvalerate) by Halomonas campisalis MCM B-1027 using agro-wastes. Int. J. Biol. Macromol. 2015, 72, 784-789. [CrossRef]

41. Khwaldia, K. Physical and mechanical properties of hydroxypropyl methylcellulose-coated paper as affected by coating weight and coating composition. BioResources 2013, 8, 3438-3452. [CrossRef]

42. Sothornvit, R. Effect of hydroxypropyl methylcellulose and lipid on mechanical properties and water vapor permeability of coated paper. Food. Res. Inter. 2009, 42, 307-311. [CrossRef]

43. Chauhan, V.S.; Bhardwaj, N.K.; Chakrabarti, S.K. Effect of particle size of magnesium silicate filler on physical properties of paper. Can. J. Chem. Eng. 2013, 91, 855-861. [CrossRef]

44. Arrieta, M.P.; López, J.; Rayón, E.; Jiménez, A. Disintegrability under composting conditions of plasticized PLA-PHB blends. Polym. Degrad. Stab. 2014, 108, 307-318. [CrossRef]

45. Siakeng, R.; Jawaid, M.; Asim, M.; Siengchin, S. Accelerated weathering and soil burial effect on biodegradability, colour and textureof coir/pineapple leaf fibres/PLA biocomposites. Polymers 2020, 12, 458. [CrossRef]

46. Arrieta, M.P.; Samper, M.D.; Aldas, M.; López, J. On the use of PLA-PHB blends for sustainable food packaging applications. Materials 2017, 10, 1008. [CrossRef] [PubMed] 